\title{
Heavy Mineral Potentiality and Alteration Studies for Ilmenite in Astaranga Beach Sands, District Puri, Odisha, India
}

\author{
Sanuprava Mohapatra ${ }^{1}$, P. Behera ${ }^{1}$, S. K. Das ${ }^{2}$ \\ ${ }^{1}$ P.G Department of Geology, Utkal University, Bhubaneswar, India \\ ${ }^{2}$ Institute of Minerals and Materials Technology, Bhubaneswar, India \\ Email: purnananda.behera@gmail.com
}

Received 4 February 2015; accepted 12 March 2015; published 25 March 2015

Copyright (C) 2015 by authors and Scientific Research Publishing Inc.

This work is licensed under the Creative Commons Attribution International License (CC BY). http://creativecommons.org/licenses/by/4.0/

(c) (†) Open Access

\section{Abstract}

Fifteen beach sand samples were collected from a depth of $1 \mathrm{mt}$ at different locations of the Astaranga beach, Puri with an interval of $300 \mathrm{mts}$. The beach sand samples were studied for heavy mineral concentration at different location points and were subjected to scanning electron microscope studies for the mineral ilmenite. The percentage of total heavy mineral in Astaranga beach varies from $16.42 \%$ to $\mathbf{2 4 . 4 7 \%}$. The important minerals are ilmenite, rutile, zircon, sillimanite, garnet, monazite, pyroxene and others. For all samples a set of sieves bearing ASTM nos. 30, 40, 60, 80, 100, 120, 140, 170 and 200 corresponding to $0.59 \mathrm{~mm}, 0.42 \mathrm{~mm}, 0.25 \mathrm{~mm}, 0.177 \mathrm{~mm}, 0.149$ $\mathrm{mm}, 0.125 \mathrm{~mm}, 0.105 \mathrm{~mm}, 0.088 \mathrm{~mm}$ and $0.074 \mathrm{~mm}$ respectively were used to separate different size fractions. The sieve mesh sizes vary from $0.59 \mathrm{~mm}$ to $0.74 \mathrm{~mm}$. It was observed that maximum concentration of heavies was confined to +200 ASTM sieve or $0.74 \mathrm{~mm}$. The total average heavy mineral concentration and light mineral concentration was found to be $20.07 \%$ and $79.49 \%$ respectively. The concentration percentage of different heavy minerals varied from higher to lower in the order like ilmenite, zircon, sillimanite, garnet, rutile, pyroxene, monazite and others. The ilmenite mineral in this area is found to have altered to secondary phases like pseudorutile, leucoxene and rutile along the fractures, cavities and grain boundaries. The alteration condition was observed as streaks, irregular patches, bands, and rim like structures around the ilmenite grains. Detailed study of alteration in ilmenite was carried out by Energy Dispersive Spectrometer (EDS) attached to Scanning Electron Microscope. The potentialities of heavies found at different locations of the Astaranga beach suggested a good source for the exploration. The alteration of the mineral ilmenite and high concentration of heavy minerals clearly pointed to the sedimentary environment and mechanical concentration process due to repeated wave action. 
Keywords

Alteration, Astaranga, Heavy Minerals, Ilmenite, SEM, EDS

\section{Introduction}

The State Odisha (India) is endowed with a long stretch of coast line for a length of $480 \mathrm{~km}$ and most part of the coast line is potentially rich with heavy minerals. Heavy mineral deposits are mostly found in the states like Kerala, Tamil Nadu, Odisha and Andhra Pradesh. The placer deposits of Chavara in Kerala, Manavalakurichi in Tamil Nadu and Chhatrapur deposit in Odisha are under active exploration by IREL (Indian Rare Earth Ltd.) of the Goverment of India and Chhatrapur deposit under the aegis of IREL is named as OSCOM (Odisha Sand Complex).

Beach placer deposits are considered as a major source of economic mineral deposit formed by sedimentary processes. Odisha has a huge reserve of about 116 million tons and Chhatrapur deposit itself has a reserve of 62.06 million tons (Padhi and Mishra, 2006) [1]. Besides Chhatrapur deposit, the other localities like Ramayapatna, Markandi, Mayurpada, Niladripur, Paluru, Malud, Astaranga and Ersama are good locations for heavy mineral exploitation. Astaranga and Ersama are located to the north and south side of the Devi river confluence with the Bay of Bengal (Figure 1). The Eastern Ghats Mobile Belt consisting of charnockite, khondalite, migmatite, granite, gneiss, etc. acts as the provenance for the coastal placer deposits of the southern coast of Odisha (Mohanty et al., (2004) [2]; Bhattacharya and Sengupta, (1994) [3], Dwivedy (1995) [4] and Behera, P. (2003) [5]). Geochemical characteristics of ilmenite sands of Chhatrapur beach placer deposits of Odisha, India was studied by PIXE and ERXRF methods by Mohanty et al. (2003) [6]. They found $\mathrm{TiO}_{2}$ within a range of 52.2 to $56.85 \mathrm{wt} \%$. Rao and Sengupta (2014) [7] studied the ilmenite in the beach placers of Chhatrapur beach, Odisha for texture, micromorphology and elemental composition by XRD and Electronmicrope. They found that the ilmenites have been weathered by chemical and mechanical processes. The $\mathrm{TiO}_{2}$ content was calculated as $50.25 \%$ to $55.41 \%$. Surekha Rao and Mishra (2009) studied the sources of ilmenite, monazite, magnetite, etc. by Isodynamic Separator and XRD [8].

The purpose of the paper is to evaluate heavy mineral concentration found at different locations of the Astaranga beach and dune areas at a depth of $1 \mathrm{mt}$. The paper also aims to study the individual heavy mineral distribution in different size fractions, the chemical characteristics of ilmenite and its alteration products. This study focuses on the study of potentiality aspect as well as the environment of deposition.

\section{Material and Methods}

\subsection{Sieving and Heavy Liquid Separation}

Fifteen beach sand samples were collected from the Astaranga beach by using a hand operated sand auger. The distance between two locations was $300 \mathrm{mt}$ and the samples were collected from a depth of $1 \mathrm{mt}$. The samples were brought to the laboratory, dried and thoroughly mixed. Each sample was reduced to 100 gms by coning and quartering processes. The samples were treated with dilute HCL to remove shell materials followed by repeated washing with water to remove the ultra fine clays. The samples were then sieved with ASTM sieve numbering 30, 40,60, 80, 100,120,140, 170, 200. After the sieving each fraction of the sample was put in a heavy liquid Bromoform (sp.gr-2.89) and the total heavy minerals concentration was calculated. The heavy mineral fractions were taken to prepare the slides for the study under the microscope. Minimum 300 grains were calculated and then number percentage was determined. The number percentage of each of the heavy minerals was multiplied with their respective specific gravity values and the wt \% of the individual member was calculated. Results obtained were recorded in a tabular form. The location map of the sample points is shown in Figure 1 and the values of the average no \% and average wt \% are shown in Table 1.

\subsection{SEM and EDS Study}

The heavy minerals were studied using a Zeiss Scanning Electron Microscope (M/s. Zeiss EVO 50-06 model). The particles were sprinkled on double-sided carbon adhesive tape fixed on an aluminium stud, carbon coated in 


\section{$86^{\circ} 30^{\prime} \mathrm{N} / 19^{\circ} 55^{\prime} \mathrm{E}$}

\section{$86^{\circ} 02^{\prime} \mathrm{N} / 19^{\circ} 55^{\prime} \mathrm{E}$}

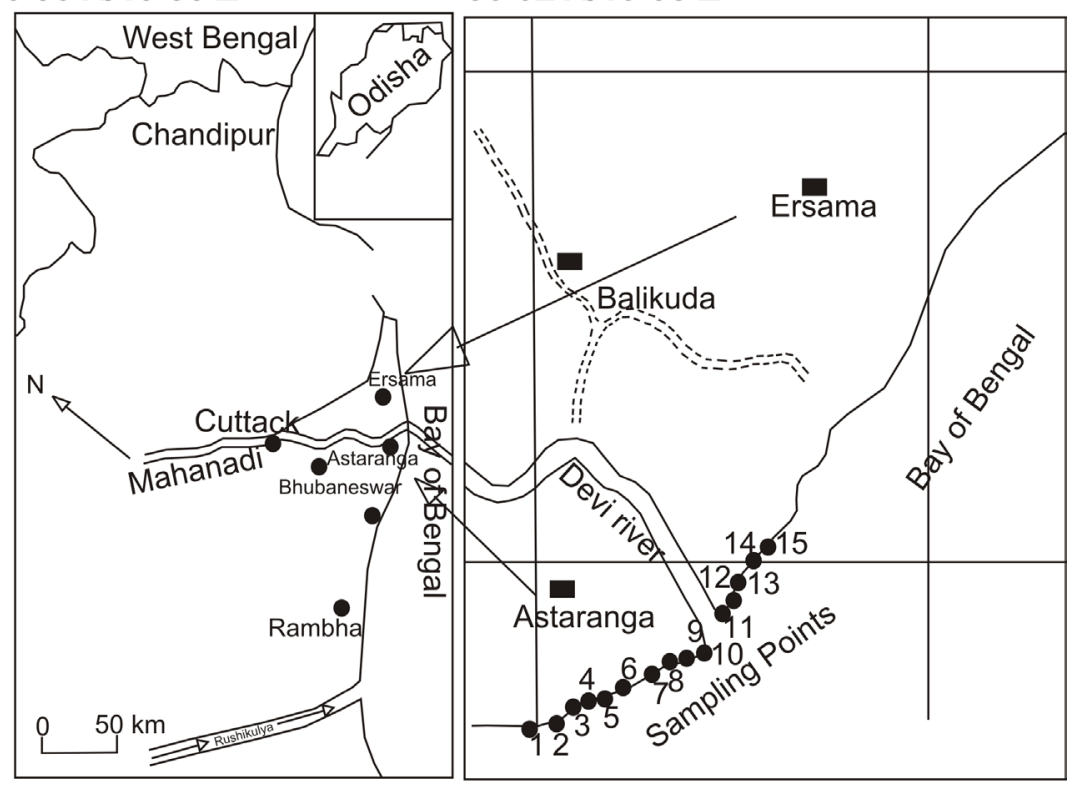

Figure 1. Location map of the study area.

Table 1. Calculation of wt \% of heavy minerals of Astaranga Beach (average values for all).

\begin{tabular}{cccccc}
\hline Sl. No. & Name of the Mineral & No $\%$ & Sp. Gravity & No \% × Sp. Gravity & Wt \% \\
\hline 1 & Ilmenite & 47.16 & 4.67 & 220.23 & 51.05 \\
2 & Rutile & 6.44 & 4.1 & 26.4 & 6.12 \\
3 & Zircon & 16.25 & 4.68 & 76.05 & 17.63 \\
4 & Sillimanite & 13.37 & 3.24 & 43.31 & 10.04 \\
5 & Garnet & 10.45 & 4.0 & 41.8 & 9.69 \\
6 & Monazite & 0.83 & 5.1 & 4.23 & 0.98 \\
7 & Pyroxene & 3.7 & 3.6 & 13.32 & 3.08 \\
8 & Others & 1.71 & 3.5 & 5.98 & \\
\hline
\end{tabular}

a vacuum sputter coater and viewed under the SEM operating at $25 \mathrm{kV}$ and a beam current of $11.0 \mu \mathrm{A}$. The chemical analysis of the minerals was performed under the SEM (M/s. Zeiss EVO 50-06 model) in a spot mode in which the electron beam was directed to a spot. The energy was detected by attached energy dispersive spectrometer (EDS) (M/s. Bruker Gmbh) and processed by the pulse processor for semi-quantitative analysis of mineral phases.

\section{Results and Discussion}

\subsection{Total Heavy Minerals (THM) in Bulk Samples and Heavy Minerals (HM) in Size Fractions}

The total heavy minerals percentage has been calculated for different samples collected at different locations. The percentage of light fractions and heavy fractions has been shown by bar diagram (Figure 2).

At Location-1 the heavy mineral \% is 17.26 and light mineral \% is $82.54 \%$. Similarly at location-2 the heavy mineral \% is 24.47 and light mineral \% is $75.56 \%$, at location-3 the heavy mineral \% is 18.69 and light mineral \% is $79.77 \%$, at location-4 the heavy mineral \% is 18.7 and light mineral \% is $80.23 \%$, at location-5 the heavy mineral \% is $20.14 \%$ and the light mineral \% is $78.01 \%$, at location- 6 the heavy mineral is $20.3 \%$ and the light $\%$ is 79.48 , at location-7 the heavy mineral \% is $23.81 \%$ and the light $\%$ is $75.97 \%$, at location- 8 the heavy mineral \% is $23.54 \%$ and the light \% is $76.33 \%$, at location- 9 the heavy mineral \% is $19.17 \%$ and the light \% is 


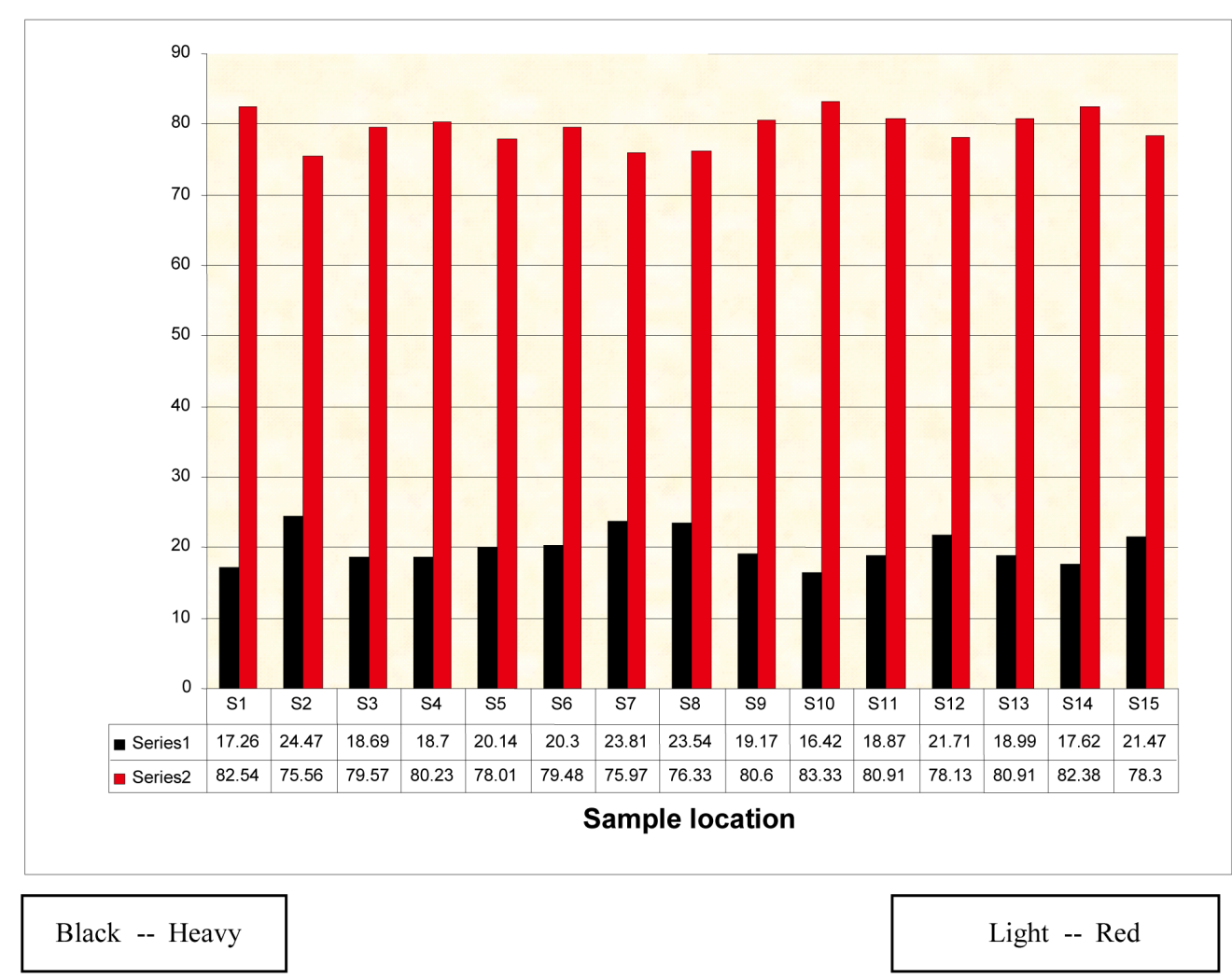

Figure 2. The total heavy mineral (THM) concentration and light fraction for the individual.

$80.6 \%$, at location-10 the heavy mineral \% is $16.42 \%$ and the light $\%$ is $83.33 \%$, at location- 11 the heavies $\%$ are $18.87 \%$ and the lights $\%$ are $80.91 \%$, at location- 12 the heavies $\%$ are $21.71 \%$ and the lights $\%$ are $78.13 \%$, at location-13 the heavies constitute $18.99 \%$ and the lights $80.91 \%$, at location-14 the heavies $\%$ are $17.62 \%$ and lights $\%$ are $82.38 \%$ and at location-15 the heavies \% found are $21.47 \%$ and the light fractions are $78.3 \%$. The heavy mineral and lighter mineral percentages of 15 locations are represented in Figure 2. Out of the 15 locations the heavy mineral \% is the highest at location- 2 and the lowest at location-10. The concentration of heavy minerals at different locations does not vary much.

The results of number percentage and weight percentage have been shown in Table 1 . The wt\% of ilmenite is highest i.e. 51.05 then it is followed by ziron (17.63\%) sillimanite (10.04\%), garnet (9.69\%), rutile (6.12\%), pyroxene $(3.08 \%)$, others $(1.38 \%)$, monazite $(0.98 \%)$. The results show the predominance of ilmenite.

\subsection{Individual Concentration of Heavies in Different Size Fractions and in Total Samples}

Fifteen beach sand samples were taken for determination of different heavy mineral species. The dominant heavy minerals indentified are ilmenite, zircon, sillimanite, garnet, rutile, pyroxenes and monazite. Amongst the heavy minerals, ilmenite, zircon, sillimanite, garnet and rutile constitute the major percentages. The number percentage and weight percentage of ilmenite is the highest in Astaranga beach and the no \% and wt \% of monazite is the lowest in that beach. In all the samples ilmenite percentages in the THM are from high to very high in $120(\mathbf{0 . 1 2 5} \mathbf{~ m m})$ to $200 \mathbf{( 0 . 0 7 4} \mathbf{~ m m})$ ASTM sieve. The data suggest that ilmenite is finer grained compared with garnet and sillimanite. Garnet and sillimanite are predominantly concentrated in coarse sizes. Zircon and monazite are concentrated below 120 ASTM sieve or within the size fraction of $0.125 \mathrm{~mm}$.

\subsection{Mineralogy}

Garnets are mainly represented by almandine and pyrope. Garnet is mostly sub rounded and sub angular, buff to brown colour with conchoidal fracture. Inclusions are noted within garnet. Sillimanite is tabular, rectangular and square like and sometimes stained by iron hydroxides. Monazite grains are rounded to elliptical, where as zircon 
grains are generally elongated with edges. Some of the zircon grains are rounded to sub rounded indicating long distance transport. Inclusions of ilmenite, quartz and monazite are observed in zircon grains. Rutile grains are tabular. Ilmenite grains are tabular, sub rounded and show complex internal structure. They vary from pure ilmenite (without any inclusions and alteration parts) to impure varieties containing exsolution lamellae of hematite and complex alteration products. The ilmenite grains are sparsely altered. Microscopic studies under reflected light reveal exsolution bands, lamellae, blebs, spots of hematite in ilmenite grains (Figure 3). The linear cavities (Figure 4) indicate leaching of hematite lamellae from ilmenite. Hematite also contains exsolution laths and streaks of ilmenite. Ilmenite grains in some cases have altered to pseudoilmenite, pseudorutile, leucoxene/ rutile along fracture, margins, cavities and structural weak planes (Figure 5). In Figure 6, the altered mineral leucoxene shows strong internal reflection under crossed nicols.

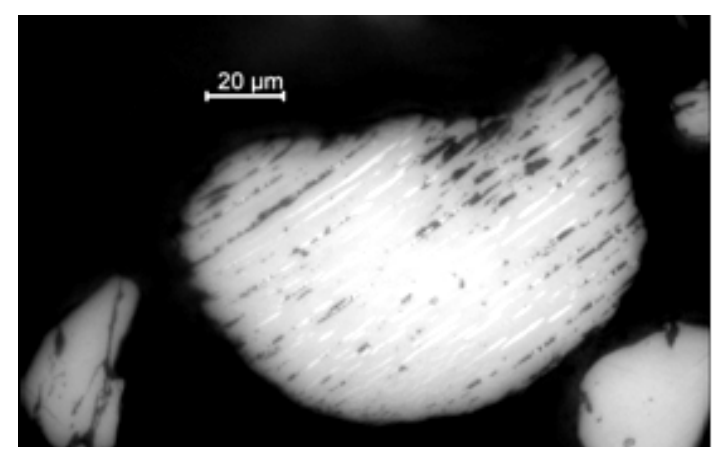

Figure 3. Fine exsolution lamellae of iron ore hematite in ilmenite grain at Astaranga, Puri.

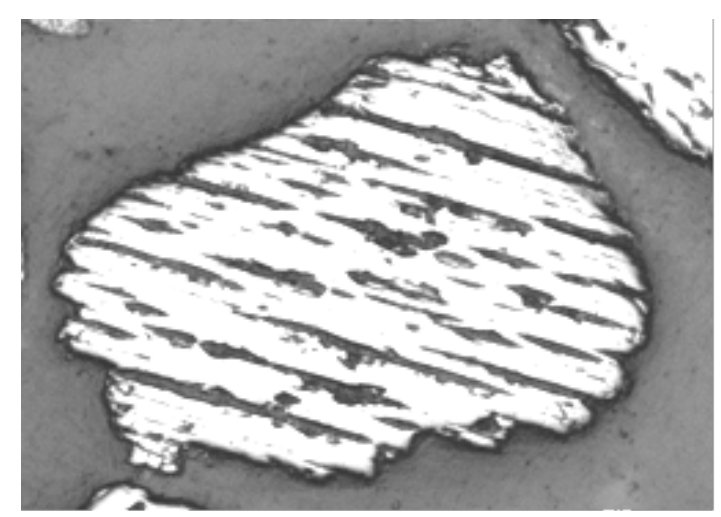

Figure 4. Parallel arrangements of linear pits within ilmenite grain, Astaranga, Puri.

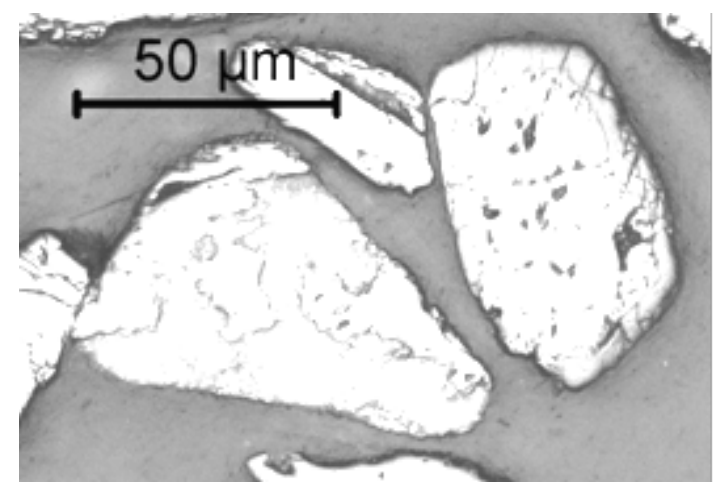

Figure 5. Leucoxene as irregular patch and as partial rim around ilmenite grains, Astarang, Puri. 


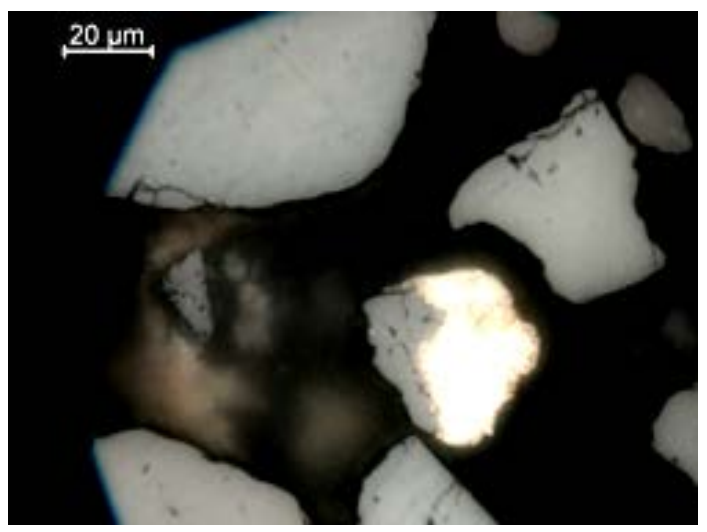

Figure 6. Leucoxene showing strong internal reflection under crossed nicols. Astarang, Puri.

\subsection{Mineral Chemistry of Ilmenite and Its Alteration Products}

Ilmenite is altered to leucoxene which is highly enriched in titanium $\left(\mathrm{TiO}_{2}=81.01 \%-96.84 \%\right)$ and depleted in iron $(\mathrm{FeO}(\mathrm{t})=1.12 \%-16.81 \%)$ contents. Silica $\left(\mathrm{SiO}_{2}\right)$ and alumina $\left(\mathrm{Al}_{2} \mathrm{O}_{3}\right)$ contents in leucoxene phase vary between $0.00 \%-8.13 \%$ and $0.00 \%-9.26 \%$. In pseudorutile phase the percents of $\mathrm{FeO}(\mathrm{t})$ and $\mathrm{TiO}_{2}$ are significantly higher and lower than leucoxene phase and vary between 31.13 to 41.04 and 57.96 to 64.13 respectively. Several authors have studied the alteration characteristics of placer ilmenite grains from India and abroad (Frost et al., 1983 [9]; Chernet, 1999 [10]). The chemistry of alteration is controlled by processes such as 1) simultaneous leaching and oxidation of ferrous iron from ilmenite to form pseudoilmenite and pseudorutile and 2) subsequent leaching of iron during the transformation of pseudorutile to leucoxene. The latter process is also associated with hydrolysation. Frost et al. (1983) [9] noted that alumina and silica were introduced to the altered phases of ilmenite from the existing environment during alteration process. The reactions for transformation of ilmenite to pseudorutile and leucoxene phases are as follows (Frost et al., 1983) [9].

$$
\begin{array}{ll}
6 \mathrm{FeTiO}_{3} \text { (ilmenite) }+1.5 \mathrm{O}_{2}+3 \mathrm{H}_{2} \mathrm{O} & 2 \mathrm{Fe}_{2} \mathrm{Ti}_{3} \mathrm{O}_{9} \text { (pseudorutile) }+2 \mathrm{Fe}(\mathrm{OH})_{3} \\
\mathrm{Fe}_{2} \mathrm{Ti}_{3} \mathrm{O}_{9} \text { (pseudorutile) }+3 \mathrm{H}_{2} \mathrm{O} & \left.3 \mathrm{TiO}_{2} \text { (leucoxene or rutile }\right)+2 \mathrm{Fe}(\mathrm{OH})_{3}
\end{array}
$$

\section{Conclusions}

1) The heavy minerals of Astaranga beach are predominantly composed of ilmenite, garnet, sillimanite, rutile, zircon, pyroxene and monazite. The percentage of total heavy minerals varies from $16.42 \%$ to $24.47 \%$. The average concentration of heavy mineral is $20.07 \%$.

2) The heavy minerals are mostly concentrated between 120 to 200 ASTM sieves, i.e. in the size fraction of $0.125 \mathrm{~mm}$ to $0.074 \mathrm{~mm}$.

3) The ilmenite is fine grained compared with garnet, sillimanite and rutile, and predominantly occurs below the size fraction $-0.125 \mathrm{~mm}$. The ilmenite constitutes $51.05 \%$ (wt \%) of total heavy minerals of the Astaranga beach.

4) Ilmenite is partly altered to pseudorutile and leucoxene which occur as fine to coarse irregular patches, blebs, streaks, laths, veins and rims.

5) Maximum concentration of heavies is found in size fractions of +200 ASTM sieve or $0.074 \mathrm{~mm}$.

6) The alteration of the mineral ilmenite and high concentration of heavy minerals clearly points to the sedimentary environment and mechanical concentration process due to repeated wave action.

\section{References}

[1] Padhi, S.K. and Mishra, P.C. (2006) Beach Sand Minerals. Geology and Mineral Resources of Odisha. Society of Geoscientists and Allied Technologists (SGAT) Publication, Bhubaneswar, 168-180.

[2] Mohanty, A.K., Sengupta, D., Das, S.K., Saha, S.K. and Van, K.V. (2004) Natural Radioactivity and Radiation Exposure in the High Background Area at Chhatrapur Beach Placer Deposits of Odisha, India. Journal of Environmental 
Radioactivity, 75, 15-33. http://dx.doi.org/10.1016/i.jenvrad.2003.09.004

[3] Bhattacharya, S. and Sengupta, R. (1994) Surface Microstructures of Heavy Minerals from Bay of Bengal off Gopalpur, Odisha. Journal of Geological Society of India, 44, 175-184.

[4] Dwivedy, K.K. (1995) Reserves, Resources and Geology of Titanium Deposits in India. Titanium, 1, 16-39.

[5] Behera, P. (2003) Heavy Minerals in Beach Sands of Gopalpur and Paradeep along Odisha Coastline, East Cost of India. Indian Journal of Marine Science, 32, 172-174.

[6] Mohanty, A.K., Vijayan, V., Sengupta, D., Das, S.K. and Saha, S.K. (2003) Geochemical Characteristics of Ilmenite Sands of Chhatrapur Beach Placer Deposit, Orissa, India: A PIXE Study. International Journal of PIXE, 13, 121. http://dx.doi.org/10.1142/S0129083503000178

[7] Rao, D.S. and Sengupta, D. (2014) Eletron Microscopic Studies of Ilmenite from Chhatrapur coast, Odisha, India and Their Implications in Processing. Journal of Geochemistry, 2014, Article ID: 192639. http://dx.doi.org/10.1155/2014/192639

[8] Srekha Rao, N. and Mishra, S. (2009) Sources of Monazite Sand in Southern Odisha Beach Placer, Eastern India. Journal of the Geological Society of India, 74, 357-362. http://dx.doi.org/10.1007/s12594-009-0140-7

[9] Frost, M.T., Grey, I.E., Harrowfield, I.R. and Mason, K. (1983) The Dependence of Alumina and Silica Contents on the Extent of the Alteration of Weathered Ilmenite from Western Australia. Mineralogical Magazine, 47, 201-208. http://dx.doi.org/10.1180/minmag.1983.047.343.10

[10] Chernet, T. (1999) Applied Mineralogical Studies on Australian Sand Ilemnite Concentrate with Special Reference to its Behaviour in Sulphate Process. Minerals Engineering, 12, 485-495. Behaviour in Sulphate Process. Minerals Engineering, 12, 485-495. http://dx.doi.org/10.1016/S0892-6875(99)00035-7 